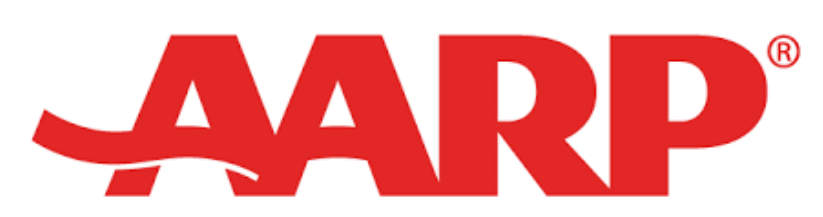

\title{
AARP Oklahoma Retirement Security Survey: Senate District 2
}

\section{ANNOTATED QUESTIONNAIRE}

\author{
Conducted by Alan Newman Research for AARP \\ https://doi.org/10.26419/res.00423.003
}

Interviews: $11 / 6 / 2020$ - 11/16/2020

203 Oklahoma registered voters, ages 25-64, residing in Senate District 2

Margin of error:

\pm 4.0 percentage points at the $95 \%$ confidence level among U.S. adults

NOTE: All results show percentages among all respondents, unless otherwise labeled.

Percentages may not always sum to $100 \%$. 


\section{AARP}

\section{AARP OKLAHOMA RETIREMENT SECURITY SURVEY: SENATE DISTRICT 2 ANNOTATED QUESTIONNAIRE}

\section{Oklahoma statewide}

Screening Criteria: Age 25-64, resident of Oklahoma's Senate District 2, registered voter in Oklahoma, employed in private sector or unemployed and looking for work;

20 minutes

Telephone (50\% cell phone $/ 50 \%$ landline)

$n=203$

All data have been weighted by age, gender, and race/ethnicity according to November 2020 Oklahoma state voter database statistics.

Hello, this is calling from , a national opinion research firm. We are not telemarketers and are not trying to sell you anything. We are interested in your thoughts about retirement security issues in Oklahoma. Your views are important, and we would greatly appreciate your participation. Your confidential responses will be summarized and shared.

S1. [AII] Our study is interested in the opinions of certain age groups. Could you please tell me your age as of your last birthday? [IN YEARS] [AGE CODED]

\begin{tabular}{|l|l|}
\hline$\%$ & $\mathrm{n}=203$ \\
\hline 0 & Under 25 (TERMINATE) \\
\hline 21 & $25-34$ \\
\hline 36 & $35-49$ \\
\hline 15 & $50-55$ \\
\hline 29 & $56-64$ \\
\hline 0 & 65 or older (TERMINATE) \\
\hline 0 & Refused (TERMINATE) \\
\hline
\end{tabular}

S2. [AIl] And just to confirm, are you a resident of Oklahoma?

\begin{tabular}{|c|l|}
\hline$\%$ & $\mathrm{n}=203$ \\
\hline 100 & Yes \\
\hline 0 & No (TERMINATE) \\
\hline 0 & Don't know/ refused (TERMINATE) \\
\hline
\end{tabular}

S3. [AII] What is your 5-digit ZIP code? OKLAHOMA) 
S4. [All] And are you registered to vote in Oklahoma?

\begin{tabular}{|c|l|}
\hline$\%$ & $\mathrm{n}=203$ \\
\hline 100 & Yes \\
\hline 0 & No (TERMINATE) \\
\hline 0 & Don't know (TERMINATE) \\
\hline 0 & Refused (TERMINATE) \\
\hline
\end{tabular}

S5. [All] To ensure it is recorded accurately, could you please state your gender?

\begin{tabular}{|c|l|}
\hline$\%$ & $\mathrm{n}=203$ \\
\hline 47 & Male \\
\hline 53 & Female \\
\hline 0 & Other (specify) \\
\hline 0 & Refused \\
\hline
\end{tabular}

S6. [All] Which of the following best describes your current employment status? Are you...? (READ LIST)

\begin{tabular}{|c|l|}
\hline$\%$ & $\mathrm{n}=203$ \\
\hline 14 & Self-employed full-time \\
\hline 7 & Self-employed part-time \\
\hline 57 & Employed full-time \\
\hline 7 & Employed part-time \\
\hline 0 & Retired and not working at all (TERMINATE) \\
\hline 16 & Unemployed and looking for work (SKIP TO Q1) \\
\hline 0 & Or are you not in the labor force for other reasons (TERMINATE) \\
\hline 0 & Don't know (VOL) (TERMINATE) \\
\hline 0 & Refused (VOL) (TERMINATE) \\
\hline
\end{tabular}

S7. [If S6=Employed full- or part-time] Are you currently employed in a federal, state, or local government job?

\begin{tabular}{|c|l|}
\hline$\%$ & $\mathrm{n}=171$ \\
\hline 0 & Yes (TERMINATE) \\
\hline 100 & No \\
\hline 0 & Don't know (TERMINATE) \\
\hline 0 & Refused (TERMINATE) \\
\hline
\end{tabular}

A1. [All] In general, are you worried or not worried about the coronavirus pandemic? Is that (very or somewhat worried)/(not too or not at all worried)?

\begin{tabular}{|c|l|}
\hline$\%$ & $\mathrm{n}=203$ \\
\hline 31 & Very worried \\
\hline 35 & Somewhat worried \\
\hline 17 & Not too worried \\
\hline 18 & Not at all worried \\
\hline 0 & Not sure $(\mathrm{VOL})$ \\
\hline 0 & Refused $(\mathrm{VOL})$ \\
\hline
\end{tabular}


A2. [AII] When you think about the coronavirus pandemic, how worried are you about.....? (READ LIST) Is that (very or somewhat worried)/(not too or not at all worried)? [RANDOMIZE]

\begin{tabular}{|l|c|c|c|c|c|c|}
\hline \multicolumn{1}{|c|}{$\mathrm{n}=203$} & $\begin{array}{c}\text { Very } \\
\text { worried } \\
\%\end{array}$ & $\begin{array}{c}\text { Somewhat } \\
\text { worried } \\
\%\end{array}$ & $\begin{array}{c}\text { Not too } \\
\text { worried } \\
\%\end{array}$ & $\begin{array}{c}\text { Not at } \\
\text { all } \\
\text { worried } \\
\%\end{array}$ & $\begin{array}{c}\text { Don't } \\
\text { know } \\
\%\end{array}$ & $\begin{array}{c}\text { Refused } \\
\%\end{array}$ \\
\hline A. Your current personal financial situation & 24 & 25 & 24 & 26 & $<1$ & 0 \\
\hline $\begin{array}{l}\text { B. Your long-term personal financial } \\
\text { situation over the next 5 years }\end{array}$ & 23 & 31 & 22 & 23 & 1 & 0 \\
\hline $\begin{array}{l}\text { C. Your health or the health of others in your } \\
\text { family }\end{array}$ & 38 & 36 & 13 & 13 & 0 & 0 \\
\hline $\begin{array}{l}\text { D. The security of your job or the job of } \\
\text { someone in your family }\end{array}$ & 20 & 26 & 22 & 29 & 2 & 1 \\
\hline
\end{tabular}

Q1. [All] As you think about your finances in the future, how anxious do you feel about having enough money to live comfortably through your retirement years? Are you...? (READ LIST)

\begin{tabular}{|c|l|}
\hline$\%$ & $\mathrm{n}=203$ \\
\hline 27 & Very anxious \\
\hline 37 & Somewhat anxious \\
\hline 18 & Not very anxious \\
\hline 15 & Not anxious at all \\
\hline 3 & Don't know (VOL) \\
\hline 1 & Refused (VOL) \\
\hline
\end{tabular}

*Q2_A. [If ages 25-34] Given the amount of money you currently have saved, do you think you'll be able to save enough money for your retirement years?

\begin{tabular}{|l|l|}
\hline$\%$ & \\
\hline & Yes \\
\hline & No \\
\hline & Don't know \\
\hline & Refused \\
\hline
\end{tabular}

*Data suppressed due to small base.

Q2_B. [If ages 35-64] Given the amount of money you currently have saved, do you wish you had more money saved for your retirement years?

\begin{tabular}{|c|l|}
\hline$\%$ & $\mathrm{n}=160$ \\
\hline 85 & Yes \\
\hline 14 & No \\
\hline 1 & Don't know \\
\hline 0 & Refused \\
\hline
\end{tabular}


Q3. [AII] How confident are you that you will have enough money to take care of your healthcare expenses during your retirement years? These expenses include things such as co-payments, deductibles, out-of-pocket drug costs, expenses that Medicare doesn't cover, such as hearing aids and eyeglasses, and possibly nursing home or longterm care. Are you...? (READ LIST)

\begin{tabular}{|c|l|}
\hline$\%$ & $n=203$ \\
\hline 15 & Very confident \\
\hline 35 & Somewhat confident \\
\hline 26 & Not very confident \\
\hline 21 & Not confident at all \\
\hline 2 & Don't know (VOL) \\
\hline$<1$ & Refused (VOL) \\
\hline
\end{tabular}

Q4. [All] How concerned are you that cost-of-living increases (over which you have no control) may reduce your standard of living? Are you...? (READ LIST)

\begin{tabular}{|c|l|}
\hline$\%$ & $\mathrm{n}=203$ \\
\hline 38 & Very concerned \\
\hline 41 & Somewhat concerned \\
\hline 11 & Not very concerned \\
\hline 9 & Not concerned at all \\
\hline 1 & Don't know (VOL) \\
\hline 0 & Refused (VOL) \\
\hline
\end{tabular}

Q5. [AII] How important is it for people to be able to save money for their retirement years while they are working? (READ LIST)

\begin{tabular}{|c|l|}
\hline$\%$ & $n=203$ \\
\hline 89 & Very important \\
\hline 10 & Somewhat important \\
\hline$<1$ & Not very important \\
\hline 1 & Not important at all \\
\hline 0 & Don't know (VOL) \\
\hline 0 & Refused (VOL) \\
\hline
\end{tabular}

Q6. [AII] When it comes to planning and saving for retirement, would you say that you are ahead of schedule, on track, or behind schedule?

\begin{tabular}{|c|l|}
\hline$\%$ & $n=203$ \\
\hline 14 & Ahead of schedule \\
\hline 32 & On track \\
\hline 51 & Behind schedule \\
\hline 3 & Don't know \\
\hline 1 & Refused \\
\hline
\end{tabular}


Q7. [If S6=Employed full- or part-time] Which of the following ways to save for retirement does your current employer provide? Do they provide...? (READ LIST) [ROTATE A-B/B-A]

\begin{tabular}{|c|l|}
\hline$\%$ & n=129 \\
\hline 22 & $\begin{array}{l}\text { A. A traditional pension plan or a defined benefit plan? [IF ASKED: “A defined benefit plan } \\
\text { supplies retirees with a monthly income, typically based on a formula of salary and years of } \\
\text { service. It is not a 401(k) plan."] }\end{array}$ \\
\hline 74 & $\begin{array}{l}\text { B. An IRA, 401(k) or 403(b) defined contribution plan? [IF ASKED: “A defined contribution plan } \\
\text { allows you to make contributions from your salary to an individual account set up in your } \\
\text { name."] }\end{array}$ \\
\hline 19 & C. (If neither above=yes, confirm:) Your employer does NOT offer a way to save for retirement. \\
\hline 1 & Don't know (VOL) \\
\hline 0 & Refused (VOL) \\
\hline
\end{tabular}

*Q7_A. [If Q7=Your employer does NOT offer a way to save for retirement, don't know, or refused] If your employer offered a way to save for retirement at work, how likely would you be to take advantage of it? (READ LIST)

\begin{tabular}{|l|l|}
\hline$\%$ & \\
\hline & Very likely \\
\hline & Somewhat likely \\
\hline & Not very likely \\
\hline & Not at all likely \\
\hline & Don't know (VOL) \\
\hline & Refused (VOL) \\
\hline
\end{tabular}

*Data suppressed due to small base.

Q8. Are you making regular contributions to any of the following savings tools...? (READ LIST) [ROTATE A-B/B-A, READ C LAST]

\begin{tabular}{|c|c|c|c|c|}
\hline$n=203$ & $\begin{array}{c}\text { Yes } \\
\%\end{array}$ & $\begin{array}{l}\text { No } \\
\%\end{array}$ & $\begin{array}{c}\text { Not sure } \\
\%\end{array}$ & $\begin{array}{c}\text { Refused } \\
\%\end{array}$ \\
\hline $\begin{array}{l}\text { A. [If Q7=An IRA, } 401(k) \text { or } 403(b) \text { defined contribution plan] A } \\
\text { workplace retirement saving plan such as a } 401(k) \text { or } 403(b) \\
\text { offered by your employer }(n=96)\end{array}$ & 83 & 16 & 1 & 0 \\
\hline $\begin{array}{l}\text { B. [All] A personal retirement savings plan such as an IRA or } \\
\text { thrift savings plan }\end{array}$ & 40 & 58 & 1 & 0 \\
\hline C. [All] Something else to help you save for retirement & 40 & 58 & 2 & 0 \\
\hline
\end{tabular}

Q9. [AII] How concerned are you as a taxpayer that some Oklahoma workers have not saved enough money for retirement and could end up being reliant on public assistance programs? Are you...? (READ LIST)

\begin{tabular}{|c|l|}
\hline$\%$ & $\mathrm{n}=203$ \\
\hline 45 & Very concerned \\
\hline 39 & Somewhat concerned \\
\hline 7 & Not very concerned \\
\hline 7 & Not concerned at all \\
\hline 2 & Don't know (VOL) \\
\hline 0 & Refused (VOL) \\
\hline
\end{tabular}


Q10. [AII] Many in Oklahoma, especially those who work for small businesses, do not have a way to save for retirement at work. One way to help more workers save would be for Oklahoma to set up a retirement savings program. The program offers retirement savings workers control by allowing them to choose whether or not to participate, decide how much to contribute, and let them take their account with them if they change jobs.

Workers save for retirement using money automatically taken out of their regular paycheck. The program would be managed as a public-private partnership. Do you support or oppose this program? Is that strongly or somewhat?

\begin{tabular}{|c|l|}
\hline$\%$ & $\mathrm{n}=203$ \\
\hline 35 & Strongly support \\
\hline 35 & Somewhat support \\
\hline 7 & Neither support nor oppose \\
\hline 5 & Somewhat oppose \\
\hline 12 & Strongly oppose \\
\hline 7 & Don't know \\
\hline 0 & Refused \\
\hline
\end{tabular}

Q11. [All] Now I'm going to read a list of some features of an Oklahoma retirement savings program being considered and l'd like you to tell me how important each would be to you. After I finish reading each statement, tell me if that feature is very important to you, somewhat important, not very important, or not at all important to you. How important is it to you that a state savings program be...? (READ LIST)

\begin{tabular}{|c|c|c|c|c|c|c|}
\hline$n=203$ & $\begin{array}{c}\text { Very } \\
\text { important } \\
\%\end{array}$ & $\begin{array}{l}\text { Somewhat } \\
\text { important } \\
\%\end{array}$ & $\begin{array}{l}\text { Not very } \\
\text { important } \\
\%\end{array}$ & $\begin{array}{c}\text { Not important } \\
\text { at all } \\
\%\end{array}$ & $\begin{array}{c}\text { Don't know } \\
\text { (VOL) } \\
\%\end{array}$ & $\begin{array}{l}\text { Refused } \\
\text { (VOL) } \\
\%\end{array}$ \\
\hline $\begin{array}{l}\text { A. Portable, so if you leave } \\
\text { one job, you can take the } \\
\text { money and account with you } \\
\text { to your next job }\end{array}$ & 84 & 11 & 1 & 3 & 1 & 1 \\
\hline $\begin{array}{l}\text { B. Set up such that } \\
\text { contributions are } \\
\text { automatically taken from } \\
\text { each paycheck before taxes }\end{array}$ & 55 & 27 & 8 & 8 & 1 & 1 \\
\hline $\begin{array}{l}\text { C. Voluntary, so participants } \\
\text { are not required to make } \\
\text { contributions }\end{array}$ & 62 & 28 & 3 & 5 & 2 & 0 \\
\hline $\begin{array}{l}\text { D. Available to all employees } \\
\text { who do not have a way to } \\
\text { save for retirement at work, } \\
\text { including those who work for } \\
\text { small businesses }\end{array}$ & 69 & 22 & 4 & 4 & 2 & 0 \\
\hline
\end{tabular}


Q12. [AII] Americans are more likely to save for retirement when they can do so out of their regular paycheck at work. Yet many workers do not have access to a workplace retirement savings plan, especially those that work at small businesses. Thinking about this, do you agree or disagree with the following statement: "Oklahoma elected officials should support legislation that makes it easier for all workers to save for retirement out of their regular paycheck." Do you agree or disagree with this statement? And is that strongly or somewhat?

\begin{tabular}{|c|l|}
\hline$\%$ & $n=203$ \\
\hline 63 & Strongly agree \\
\hline 25 & Somewhat agree \\
\hline 4 & Neither agree nor disagree \\
\hline 3 & Somewhat disagree \\
\hline 4 & Strongly disagree \\
\hline 1 & Don't know \\
\hline$<1$ & Refused \\
\hline
\end{tabular}

Q13. [AII] Thinking about the many concerns and issues that workers and employers are facing today related to the impact of the COVID-19 pandemic, do you agree or disagree that access to a workplace savings program is important for employees of small businesses and sole business owners in Oklahoma? (Is that strongly or somewhat?)

\begin{tabular}{|c|l|}
\hline$\%$ & $\mathrm{n}=203$ \\
\hline 55 & Strongly agree \\
\hline 28 & Somewhat agree \\
\hline 8 & Neither agree nor disagree \\
\hline 2 & Somewhat disagree \\
\hline 4 & Strongly disagree \\
\hline 3 & Don't know \\
\hline 1 & Refused \\
\hline
\end{tabular}

Thank you. Now, I just have a few more questions about how the Coronavirus pandemic has impacted your finances.

Q14. [AII] Has your household income declined since the coronavirus outbreak?

\begin{tabular}{|c|l|}
\hline$\%$ & n=203 \\
\hline 51 & Yes \\
\hline 49 & No \\
\hline 0 & Don't know \\
\hline 0 & Refused \\
\hline
\end{tabular}

Q15. [All] At any time since March of this year, were you or anyone in your household laid off or furloughed from a job because of the coronavirus outbreak?

\begin{tabular}{|c|l|}
\hline$\%$ & $\mathrm{n}=203$ \\
\hline 44 & Yes \\
\hline 56 & No \\
\hline$<1$ & Don't know \\
\hline 0 & Refused \\
\hline
\end{tabular}


Q16. [All] And at any time since March of this year, have you or anyone in your household had to take a cut in pay at work due to reduced hours?

\begin{tabular}{|c|l|}
\hline$\%$ & $\mathrm{n}=203$ \\
\hline 35 & Yes \\
\hline 64 & No \\
\hline 1 & Don't know \\
\hline 1 & Refused \\
\hline
\end{tabular}

Q17. [If any of Q8=Yes] Prior to the coronavirus outbreak, approximately what percent of your total income were you saving on average each month in retirement plans, such as a 401k, IRA, or another retirement plan? [READ LIST]

\begin{tabular}{|c|l|}
\hline$\%$ & $\mathrm{n}=149$ \\
\hline 5 & $0 \%$ \\
\hline 22 & $1 \%$ to $5 \%$ \\
\hline 28 & $6 \%$ to $10 \%$ \\
\hline 15 & $11 \%$ to $15 \%$ \\
\hline 15 & $16 \%$ to $20 \%$ \\
\hline 5 & More than $20 \%$ \\
\hline 10 & Don't know (VOL) \\
\hline 1 & Refused (VOL) \\
\hline
\end{tabular}

Q18. [If any of Q8=Yes] Since the coronavirus outbreak, approximately what percent of your total income are you saving now in retirement plans, such as a 401k, IRA, or another retirement plan? [READ LIST]

\begin{tabular}{|c|l|}
\hline$\%$ & $\mathrm{n}=149$ \\
\hline 14 & $0 \%$ \\
\hline 28 & $1 \%$ to $5 \%$ \\
\hline 20 & $6 \%$ to $10 \%$ \\
\hline 7 & $11 \%$ to $15 \%$ \\
\hline 13 & $16 \%$ to $20 \%$ \\
\hline 4 & More than $20 \%$ \\
\hline 12 & Don't know (VOL) \\
\hline 2 & Refused (VOL) \\
\hline
\end{tabular}

Q19. [All] Have your attitudes about saving for your retirement changed since the coronavirus outbreak in the U.S.?

\begin{tabular}{|c|l|}
\hline$\%$ & n=203 \\
\hline 26 & Yes \\
\hline 70 & No \\
\hline 4 & Don't know \\
\hline 1 & Refused \\
\hline
\end{tabular}


Q20. [If any of Q8=Yes] What actions have you taken since the coronavirus outbreak in the U.S. in regard to your savings in retirement plan(s)? [READ LIST; ACCEPT MULTIPLE RESPONSES EXCEPT FOR 1-2 (MUTUALLY

EXCLUSIVE) AND 8] [RANDOMIZE ORDER OF 1-6]

\begin{tabular}{|c|l|}
\hline$\%$ & $\mathrm{n}=148$ \\
\hline 17 & Reduced the amount you are contributing \\
\hline 19 & Re-allocated money to different investment(s) within your plan \\
\hline 11 & Are no longer contributing \\
\hline 5 & Withdrew some money early \\
\hline 4 & Took a loan against your 401(k) or other retirement savings account \\
\hline 3 & Withdrew all money early \\
\hline 2 & Other (specify) \\
\hline 56 & You have not taken any action with your retirement savings \\
\hline$<1$ & Don't know or refused (VOL) \\
\hline
\end{tabular}

Q21. What financial steps, if any, are you taking as a result of the coronavirus outbreak? [READ LIST, ALLOW MULTIPLE RESPONSES FOR 1-8; RANDOMIZE ORDER OF 1-7]

\begin{tabular}{|c|l|}
\hline$\%$ & $\mathrm{n}=203$ \\
\hline 57 & Reducing nonessential spending \\
\hline 43 & Postponing large financial decisions (e.g. buying a house, furniture, car) \\
\hline 25 & Finding more affordable options (e.g. health, car, or life insurance) \\
\hline 21 & Building up an emergency savings fund \\
\hline 19 & Postponing payments to companies or lenders who are offering a grace period or relief \\
\hline 13 & Buying more items on credit \\
\hline 11 & Reallocating what would have been savings for retirement to an emergency fund \\
\hline 5 & Other (specify) \\
\hline 20 & None of the above \\
\hline 0 & Don't know or refused (VOL) \\
\hline
\end{tabular}

The following questions are for classification purposes only and will be kept entirely confidential.

D1. [AII] Do you do something to earn extra money that is not your main source of income?

\begin{tabular}{|c|l|}
\hline$\%$ & $n=203$ \\
\hline 28 & Yes \\
\hline 69 & No \\
\hline 1 & Don't know \\
\hline 1 & Refused \\
\hline
\end{tabular}


D2. [AII] What is the highest level of education that you completed? (READ LIST)

\begin{tabular}{|c|l|}
\hline$\%$ & $\mathrm{n}=203$ \\
\hline 1 & 0-12th grade (no diploma) \\
\hline 17 & High school graduate (or equivalent) \\
\hline 21 & Post-high school education (no degree) \\
\hline 19 & 2-year college degree \\
\hline 31 & 4-year college degree \\
\hline 2 & Post-graduate study (no degree) \\
\hline 8 & Graduate or professional degree \\
\hline 0 & Don't know (VOL) \\
\hline 1 & Refused (VOL) \\
\hline
\end{tabular}

D3. [All] What is your current marital status? Are you currently...? (READ LIST)

\begin{tabular}{|c|l|}
\hline$\%$ & $n=203$ \\
\hline 66 & Married \\
\hline 3 & Not married, living with your partner \\
\hline 1 & Separated \\
\hline 14 & Divorced \\
\hline 1 & Widowed \\
\hline 16 & Single and never been married \\
\hline 0 & Don't know (VOL) \\
\hline 0 & Refused (VOL) \\
\hline
\end{tabular}

D4. [If D3=Married or not married living with your partner and ages 40-64] Are you or your (spouse/partner) currently a member of A-A-R-P? [If D3=Separated, divorced, widowed, single and never been married, don't know, or refused and ages 50-64] Are you currently a member of A-A-R-P?

\begin{tabular}{|c|l|}
\hline$\%$ & $\mathrm{n}=126$ \\
\hline 22 & Yes \\
\hline 78 & No \\
\hline 0 & Don't know \\
\hline 0 & Refused \\
\hline
\end{tabular}

D5. [All] Are you of Hispanic, Spanish, or Latino origin or descent?

\begin{tabular}{|c|l|}
\hline$\%$ & n=203 \\
\hline 2 & Yes \\
\hline 98 & No \\
\hline 0 & Don't know \\
\hline 0 & Refused \\
\hline
\end{tabular}


D6. [All] What is your race? Are you...? (READ LIST)

\begin{tabular}{|c|l|}
\hline$\%$ & $\mathrm{n}=203$ \\
\hline 89 & White or Caucasian \\
\hline 8 & American Indian or Alaska Native \\
\hline 1 & Black or African American \\
\hline 1 & Asian \\
\hline$<1$ & Native Hawaiian or other Pacific Islander \\
\hline 1 & Other (specify) \\
\hline 0 & Don't know (VOL) \\
\hline 1 & Refused (VOL) \\
\hline
\end{tabular}

D7. [All] Do you consider yourself to be a....? (READ LIST) [RANDOMIZE ORDER OF 1-3; READ 4 ('Something else') LAST]

\begin{tabular}{|c|l|}
\hline$\%$ & n=203 \\
\hline 29 & Democrat \\
\hline 52 & Republican \\
\hline 14 & Independent \\
\hline 3 & Something else (specify) \\
\hline$<1$ & Don't know (VOL) \\
\hline 2 & Refused (VOL) \\
\hline
\end{tabular}

D8. [All] How would you characterize your political views? (READ LIST)

\begin{tabular}{|c|l|}
\hline$\%$ & $\mathrm{n}=203$ \\
\hline 24 & Very conservative \\
\hline 26 & Somewhat conservative \\
\hline 29 & Moderate \\
\hline 11 & Somewhat liberal \\
\hline 7 & Very liberal \\
\hline$<1$ & None of the above/ something else (VOL) \\
\hline 3 & Don't know (VOL) \\
\hline 2 & Refused (VOL) \\
\hline
\end{tabular}

D9. [All] Do you own or rent your primary residence?

\begin{tabular}{|c|l|}
\hline$\%$ & $\mathrm{n}=203$ \\
\hline 81 & Own \\
\hline 13 & Rent \\
\hline 4 & Live with family \\
\hline 1 & Live with friends \\
\hline 0 & Something else (specify) \\
\hline 0 & Don't know \\
\hline 0 & Refused \\
\hline
\end{tabular}


D10. [All] We realize income is a private matter and so rather than ask you anything specific about your income, l'd like to ask you to please stop me when I get to the category that includes your household's income before taxes in 2019. Was it...? (READ LIST)

\begin{tabular}{|c|l|}
\hline$\%$ & $\mathrm{n}=203$ \\
\hline 2 & Less than $\$ 10,000$ \\
\hline 3 & $\$ 10,000$ to less than $\$ 20,000$ \\
\hline 4 & $\$ 20,000$ to less than $\$ 30,000$ \\
\hline 10 & $\$ 30,000$ to less than $\$ 40,000$ \\
\hline 12 & $\$ 40,000$ to less than $\$ 50,000$ \\
\hline 6 & $\$ 50,000$ to less than $\$ 60,000$ \\
\hline 10 & $\$ 60,000$ to less than $\$ 75,000$ \\
\hline 18 & $\$ 75,000$ to less than $\$ 100,000$ \\
\hline 15 & $\$ 100,000$ to less than $\$ 125,000$ \\
\hline 8 & $\$ 125,000$ to less than $\$ 150,000$ \\
\hline 6 & $\$ 150,000$ to less than $\$ 200,000$ \\
\hline 1 & $\$ 200,000$ or more \\
\hline 3 & Don't know (VOL) \\
\hline
\end{tabular}


AARP is the nation's largest nonprofit, nonpartisan organization dedicated to empowering Americans 50 and older to choose how they live as they age. With nearly 38 million members and offices in every state, the District of Columbia, Puerto Rico, and the U.S. Virgin Islands, AARP works to strengthen communities and advocate for what matters most to families with a focus on health security, financial stability and personal fulfillment. AARP also works for individuals in the marketplace by sparking new solutions and allowing carefully chosen, high-quality products and services to carry the AARP name. As a trusted source for news and information, AARP produces the nation's largest circulation publications, AARP The Magazine and AARP Bulletin. To learn more, visit www.aarp.org or follow @AARP and @AARPadvocates on social media.

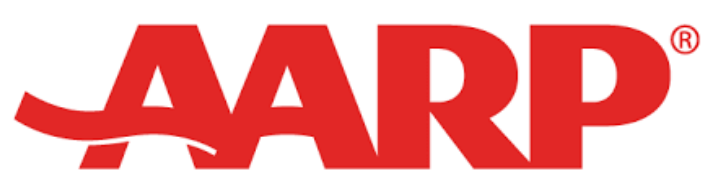

For more information on this issue in Oklahoma, contact Chad Mullen, Associate State Director - Advocacy, AARP Oklahoma at 405-715-4470 or CHMullen@aarp.org. For more information on the methodology or the survey, contact Lona Choi-Allum at 202-434-6333 or LAllum@aarp.org. View this summary at www.aarp.org/oksavetoretire and other AARP research at www.aarp.org/research. 